\title{
Macroeconomic Variables, the Oil, and the Agricultural Sectors in Nigeria
}

\author{
Adegbemi Babatunde Onakoya $^{1} \&$ Hassan Akolade Alayande ${ }^{1}$ \\ ${ }^{1}$ Department of Economics, Veronica Adeleke School of Social Sciences, Babcock University, Ilishan - Remo, \\ Nigeria \\ Correspondence: Adegbemi Babatunde Onakoya. E-mail: onakoyaa@babcock.edu.ng
}

doi:10.5539/ass.v16n1p69

URL: https://doi.org/10.5539/ass.v16n1p69

\begin{abstract}
The present study examined the impact of the macroeconomic variables and the oil sector on the performance of the agricultural sector between 1981 and 2017 in Nigeria. The study adopted a three-stage estimation approach. The initial step in this estimation was the conduct of descriptive statistics and stationarity tests of the variables. Some of the series were stationary at level and some others at the first difference which informed the deployment of the Auto regressive distributed lag (ARDL) technique for model estimation. The third stage was the post-estimation of the model in order ascertain its robustness for predictability and policy formulation. These were the Cumulative Sum Control Chart (CUSUM) stability, Vector Error Correction (VEC) Residual Heteroscedasticity, Breusch-Godfrey Serial Correlation LM, Vector Error Correction Residual Normality, and Vector Error Correction (VEC) Residual Heteroscedasticity tests. The results indicated that contrary to the Dutch disease postulation the oil sector positively impacted the output of the agricultural sector. The influence of exchange rate was also positive. Interest and unemployment rates on the other hand, had negative effects. The rate of inflation and the national output had no impact. The study recommended that the Nigerian government should channel resources towards the agricultural sector to ensure increase in foreign earnings and sufficient domestic production.
\end{abstract}

Keywords: agricultural sector, inflation rate, interest rate, GDP growth rate, unemployment rate, real exchange rate, oil sector

\section{Introduction}

Prior to the discovery of oil in 1956, the agricultural sector was undisputedly the mainstay of the economy and the primary source of revenue for the country. It was the cornerstone of the Nigerian economy due to her large exports of rubber, groundnut, hides and skin, cocoa, coffee, palm oil and palm kernel (Sylvester 2018). In the 1960 s, agriculture provided $65 \%$ of the total output of the GDP, more than $80 \%$ of Nigerian export earnings and about $50 \%$ of government revenue (PWC, 2019). The sector contributed on the average, about $35 \%$ of the Nigerian GDP and $88 \%$ of the foreign exchange income derived from the non-oil exports. (Central Bank of Nigeria, 2010) It also provided employment for about $70 \%$ of the labour force (World Development Indicators, 2017).

This has changed. The ascendancy of the oil sector in the 1970s precipitated the government's loss of enthusiasm for agricultural sector. Due to the overdependence on oil and the exogenously (international) determined pricing and production quotas, the shocks to the macroeconomic variables portend economy instability. This deepened the possible outlook of other sectors such as the agriculture, manufacturing and service sectors. The volatility of oil prices is a key factor affecting the behavior of macroeconomic variables which arose from the sometimes conflicting fiscal, monetary and trade policies of developing economies (Guo \& Kliesen, 2005; Narayan \& Narayan, 2007; Salisu \& Fasanya, 2013).

The various macroeconomic variables (unemployment, interest, inflation, exchange and the consequently, the GDP growth rates) have vacillated every year. The inflation rate rose continuously throughout 2016. Indeed, consumer prices moved to $17.6 \%$ in September from 12.8\% in March 2016. A year-on-year comparison showed that in January of 2017 , the core inflation rate stood at $17.85 \%$ as against the correspondent period in the previous year. Foreign direct investments plummeted by about $9.5 \%$ in 2016 while the foreign portfolio investment dipped by about $24 \%$ in the same year. About 4.6 million people joined the unemployment market in August 2017 ((https://tradingeconomics.com/nigeria). These prevailing macroeconomic variables which are 
managed using the monetary, fiscal, and trade policies had also not been consistently applied. Sometimes, policy summersault has sent mixed signals to economic agents and participants with deleterious consequences.

There are conflicting findings on the impact of the macroeconomic variables on the agricultural sector of the economy. Oluwatoyese, Applanaidu and Razak (2016) argued that whereas interest rate was a significant influence, inflation rate, unemployment rate were regarded as inconsequential. Adama, Ibrahim and Danjuma (2015) concluded that interest rate, inflation rate and exchange rate had significant impact on the agricultural sector, unemployment was of no importance. Sunday, Samuel and Inimfon (2015) established the fact that inflation rate and unemployment rate were the significant determinants of the outputs of the sector. These conflicting findings make this research necessary.

In addition, most of the studies investigations in the Nigerian case did not include the impact of the oil sector. The importance of the oil and gas sector which according to OPEC (2018), account for about 10 per cent of the Nigerian GDP, and about 83 per cent of its total exports revenue cannot be over emphasised. This study therefore paid particular focus on the relationship between the oil and agricultural sectors especially in view of the hypothesized Dutch disease effect. This investigation contributes to knowledge and the understanding of the workings of the economy in Nigeria, as it relates to the extent of the influence of the macroeconomic variables especially the oil sector on the agricultural sector in Nigeria between 1981 and 2017.

\section{Literature Review}

\subsection{Theoretical Review}

Given the multifarious nature of the macroeconomic variables, many theories lend themselves to use. The theory underlining the relationship between oil sector and the growth of the economy is borne out of the co-existence of abundant natural resources and acute decline in the performance of other sectors referred to as the 'Dutch disease' (Auty, 1993).

The endogenous growth theory developed by Lucas (1988) and Romer (1990) as a reaction to the flaws, omissions and deficiencies in the Solow-Swan neoclassical growth model argues that long run economic growth is precipitated by endogenous factors as against the exogenous factors of the neoclassical growth theory. This theory recognizes the endogeniety of technological change. It also identifies the key role played by the stock of both human and non-human capital in the generation of positive externalities. As explained by Muftaudeen and Hussainatu (2014) they are not necessarily subject to diminishing returns to scale. The endogenous growth theory which basically elucidates that economic growth is generated from within the system as a direct result of internal processes is pertinent to the study because it signifies that growth in the agricultural sector is dependent on domestic operations. The Keynesian liquidity theory of interest rate is relevant to the study because it explains the influence of the rate of interest on the willingness of an individual to either invest in agriculture which is a long term investment.

The Okun's law is also relevant to this study because it brings to the fore the influence of unemployment rate on the GDP. Since agriculture is a prominent sector when taking Gross Domestic Product (GDP) into consideration in Nigeria, it creates a basis to analyze the influence of unemployment rate on the agricultural sector. The pristine Okun's law (1962) stipulates that if GDP grows rapidly, the unemployment rate will decrease. If GDP growth is very low or negative the unemployment rate rises. On the other hand, if growth equals its potential level, the unemployment rate remains unchanged (Patrick \& Prudence, 2013). Therefore, to reduce unemployment, it is mandatory for the GDP growth rate to be above the growth rate of potential output (Tarron, Jeff, \& Willi, 2006). However, this relationship has been held to be uncertain because several other factors are involved with changes in GNP and GDP. Indeed, the new

Keynesian theory contends that the emergence of active labour unions had distorted the employment-growth equilibrium in the economy. In the face of adequate unemployment of factors of production, Myrdal (1968) propounded the Structural Inflation theory. He posited that in developing economies, the aggregative demandsupply model cannot adequately explain inflation because of the dearth of balanced integrated economic structure. The substitutability quotients between production and consumption are low. In addition, there are rigidities in the inter-sectoral flow of resources. Therefore, the financing of investments through the expansion of money supply can only serve as the proximate explanation of inflation in these economies.

The Phillips (1958) curve suggests that if the demand for labour is high relative to its supply then the equilibrium wage rates would be anticipated to rise above current wage levels and there would be an upward pressure on nominal wages as firms demand for additional workers. In effect, the growth rate of nominal wages was negatively dependent on the rate of unemployment. This implies that a low unemployment rate is associated with 
rapidly rising wages while high unemployment rate is related to slowly rising wages (Orji et al., 2015).

Phillips never claimed that his results had significant policy implications, particularly policies designed to reduce unemployment. Samuelson and Solow (1960) were the catalysts that championed the usage of the Phillips curve as a policy tool and brought about the inverse relationship between inflation and unemployment. This implies that a focus on decreasing unemployment increases inflation and increasing inflation decreases unemployment. The Phillips cure has been held to be applicable by Friedman (1968) only in the short-run. The Phillips curve is pertinent to the study because it suggests that to ensure an increase in the employment rate in the agricultural sector the country must be willing to endure some inflation in the short run.

\subsection{Empirical Review}

The investigation conducted by Jungho and Won (2010) on the impact of the performance of the agricultural sector on the United States of America economy utilised the Phillips-Hansen fully modified cointegration (FM-OLS) method. The study report ascertained that interest rate and commodity price significantly determine the farm income in the United Statres of America both in the short and long term. Although also significant, the exchange rate was relevant only in the long run. The relevance of inflation rate was not investigated. Using VAR and Error correction methods, Donald, Pin and William (1993) scrutinized the impact of domestic and foreign macroeconomic variables on U.S meat exports from 1971 to 1988. The findings revealed that a shock in the foreign money supply was significant while the domestic money supplies shock had inconsequential impact on meat exports.

Lajos and Imre (2005) scrutinized the influence of macroeconomic variables on the Hungarian agriculture. The data which covered (1997-2004) was analyzed using Johansen's cointegration test and Vector error correction model (VECM). They reported the transmission of the effect of macroeconomic variables shocks on the agricultural sector. The empirical evidence obtained from developing economies is mixed. Mousavi and Leelavathi (2013) investigated the relationship between exchange rates and agricultural exports in India between 1980 and 2010 using the Granger causality test. They found no long run relationship between agricultural export and exchange rates. Similar study by Dicle (2017) covering 1961 and 2013 in India came to the same conclusion.

A Ghanaian research to ascertain the macroeconomic factors that influence agricultural production in Ghana was conducted by Enu and Attah-Obeng-Attah (2013). The study covered 1980 and 2011 and utilised the Ordinary Least Squares method. The report indicates that inflation, labour force, real exchange rate and real GDP per capita were statistically significant in determining agricultural output. Similar investigation and method by Vitalis \& Millicent (2017) in Kenya report a positive relationship between current account balance, GDP, government expenditure and commercial bank credit to agriculture to the level of agricultural output. The interest rate however has an inverse influence.

The impact of real exchange rate changes on the South African agricultural exports between 1991 and 1999 was investigated by Poonyth and Zyl (2000) using error correction model. The findings established a short-run unidirectional casual flow from the exchange rate to agricultural exports. It was also found that there is a long-run relationship between the real exchange rate and the South African agricultural sector.

With respect to empirical evidence from Nigeria, similar conflicting relationships were observed. Kareem et al (2013) who studied the factors influencing agricultural output in Nigeria used regression analysis and Granger causality teats to analyze data from 1977 to 2011 . The result shows positive relationship between foreign direct investment, commercial bank loan, interest rate, food import value on agricultural output. Similar study and method by Oyetade, Applanaidu, Applanaidu and Razak (2016) from 1981 to 2013, found that food import, banks loan to agriculture, and interest rate are significant in shaping agricultural output in Nigeria. However, exchange rate, inflation rate and unemployment rate were regarded as inconsequential.

Investigation by Sunday, Samuel and Inimfon (2015) used the Granger causality and Johansen cointegration techniques in the investigation of agricultural diversification programmes between 1960 and 2014. They identified credit to agricultural sector, inflation, energy consumption as positive drivers. On the other hand, crude oil prices, lending capacity of commercial bank, foreign direct investment in agricultural sector and non-oil import were found to negatively influence of agriculture output. Both exchange rate and credit to the sector were found to be inconsequential by Adama, Ibrahim, Danjuma (2015) who researched into the impact of growth of the agricultural sector and the impact on the Nigerian macroeconomic environment thereon using VAR model and Granger causality test. Similar significant contribution was found by Odior (2014) using the Im, Pesaran and Shin unit root test.

Some other factors were identified in the study conducted by Adama, Ibrahim and Danjuma (2015) in a study 
covering 1986 and 2010 using the VAR model and Granger causality test. They reported favourable exchange rate, reduction in the level of inflation and amelioration in the level of investment in agriculture had significant and profound effect on agricultural output. Aroride, Ogunbadejo (2014) also reported that interest rate, loans (commercial) to agriculture, and exchange rate have positive influences while money supply has a negative influence. The GDP, commercial loan to agriculture and money supply are the strongest influences. Interest rate was found not to be of significant effect. Iganiga and Unemhilin, (2017) found government capital expenditure to be positively related to agricultural output while total credit to agriculture and population growth rate were negative. Ali, Agbo, Ukwuabaand Chimela (2017) found that low interest rate was beneficial to agricultural output. Oye, Inuwa and Muhammad (2011) showed that the rate of unemployment affects the value of the GDP.

\section{Methodology}

\subsection{Data Sources}

The data for the output of the Agricultural sector and rates of the independent variables were extracted from the World Bank Development Indicators (2017), Central Bank of Nigeria Statistical Bulletin and National Bureau of Statistics (2017).

\subsection{Model Specification}

The model used in this research work was based on the Keynesian product and money market (IS-LM) function and adapted from the work, of Vitalis and Millicent (2017). The econometric model is stated in equation (1) as:

LnAgric $_{G D P}=B_{0}+B_{1} G D P_{r}+B_{2} I n f+B_{3}$ Int $+B_{4}$ Unemp $+B_{5}$ Reer $+B_{6}$ LnOil $_{G D P}+e_{t}$

where:

Agric $_{\text {gdp }}=$ Agricultural Sector Gross Domestic Product

$G D P_{r}=$ Gross Domestic Product Growth Rate

Inf $=$ Inflation Rate

Int $=$ Interest Rate

Unemp $=$ Unemployment Rate

Reer $=$ Real Exchange Rate

$O i l_{g d p}=$ Oil Revenue as a ratio of Gdp

$\mathrm{e}=$ error term

$\mathrm{t}$ is the time period; $B_{0}$ is the intercept; $B_{1}-B_{6}$ are the parameters to be estimated.

The inclusion of the oil sector is because of the significant contribution of the sector to the economy and its perceived influence on the agricultural sector.

\subsection{Estimation Technique}

The study adopted a three-stage estimation approach. The initial step in this estimation was the conduct of descriptive statistics and stationarity tests of the variables. The descripitive statistics was intended to meaningfully summarise the data and check the presence of outliers in order to determine whether ot not the data is normally distributed or not. The stationarity test was conducted using the Augmented Dickey Fuller (Dickey and Fuller (1979) and Phillip Perronunit root tests. They were conducted to ascertain the validity and reliability of the data prior to the usage of other tests.

The second stage which is the main utilized the Auto regressive distributed lag Cointegration test (ARDL) because some of the series were stationary at level and some others are stationary at the first difference. The third stage is the post-estimation of the model in order ascertain its robustness for predictability and policy formulation. These are (i) the CUSUM stability test used to determine if the model is stable or not. The model is stable if the plot of the CUSUM lies within the straight line to present the critical bound at $5 \%$ level of significance (ii) Breusch Godfrey Serial Correlation LM test (iii) normality tests and (iv) heteroscedasticity test developed by Breusch and Pagan (1979). The views (E-Views) 9.0 software package was deployed for statistically measurement 


\section{Results and Discussion}

\subsection{Preliminary Analysis}

\subsubsection{Descriptive Statistics}

The nature of the data and summary of the statistics of the various variables are presented in Table 1.

Table 1. Results of Descriptive Statistics

\begin{tabular}{cccccccc}
\hline Statistics & GDP & LnAgricgdp & Inf & Int & Unemp & Reer & LnOilgdp \\
\hline Mean & 3.21 & 7.0 & 19.52 & 0.05 & 12.07 & 82.08 & 6.07 \\
Median & 4.23 & 7.3 & 12.88 & 3.69 & 8.20 & 92.69 & 6.51 \\
Maximum & 15.33 & 10.1 & 72.84 & 25.28 & 38.20 & 305.80 & 9.33 \\
Minimum & -13.13 & 2.84 & 5.38 & -43.57 & 1.80 & 0.62 & 1.45 \\
Std. Dev. & 5.61 & 2.44 & 17.45 & 16.39 & 9.71 & 79.92 & 2.69 \\
Skewness & -0.88 & -0.32 & 1.70 & -0.98 & 0.97 & 0.74 & -0.46 \\
Kurtosis & 4.45 & 1.65 & 4.68 & 3.90 & 3.01 & 2.96 & 1.83 \\
Jarque-Bera & 8.01 & 3.45 & 22.15 & 7.10 & 5.75 & 3.40 & 3.38 \\
Probability & 0.02 & 0.18 & 0.00 & 0.03 & 0.06 & 0.18 & 0.18 \\
Sum & 118.72 & 257.58 & 722.21 & 1.99 & 446.70 & 3,037 & 224.44 \\
SumSq.Dev & $1,133.4$ & 213.53 & $10,962.7$ & $9,671.19$ & $3,393.55$ & 229,950 & 260.48 \\
Observations & 37 & 37 & 37 & 37 & 37 & 37 & 37 \\
\hline
\end{tabular}

Source: Authors' computation using E-views 9.0 (2019)

There are significant variations in the trends of the variables as manifested by the gap between the minimum and maximum values. The agricultural sector output, oil sector output, growth rate of GDP and real interest rate were negatively skewed while variables such as inflation rate, exchange rate and unemployment rate were positively skewed. However, inflation rate had the longest tail tending to the right because it possessed the largest value. The values for inflation rate, GDP growth rate and real interest rate were 4.68, 4.45 and 3.90 respectively were leptokurtic because indicative of a higher than normal distribution pattern. Others were platykurtic. These characteristics manifest the non-normality of the variables.

\subsubsection{Stationary Test Results}

The results of Augmented Dickey Fuller and Phillip Perron stationarity tests are identical. They showed that agricultural output, oil output, exchange rate, inflation rate, unemployment rate were not stationary at level $(\mathrm{I}(0))$ because their absolute ADF t-statistic value were less than their respective critical values at $5 \%$. The values were however stationary at first difference (I(1)).

Table 2. Result Augmented Dickey Fuller and Phillip Perron Stationarity Tests

\begin{tabular}{ccccccc}
\hline \multirow{2}{*}{ Series } & \multirow{2}{*}{$\begin{array}{c}\text { L Critical } \\
\text { Value }\end{array}$} & $\begin{array}{c}\text { ADF } \\
(\text { Prob })\end{array}$ & $\begin{array}{c}\text { PP Statistics } \\
(\text { Prob) }\end{array}$ & $\begin{array}{c}\text { ADF } \\
(\text { Prob) }\end{array}$ & $\begin{array}{c}\text { PP Statistics } \\
\text { (Prob) }\end{array}$ & $\begin{array}{c}\text { Order of } \\
\text { Integration }\end{array}$ \\
\cline { 3 - 6 } & & $-1.89(0.33)$ & $-4.06(0.00)$ & $-3.83(0.01)$ & $-9.86(0.00)$ & $\mathrm{I}(1)$ \\
LnAgric $_{G D P}$ & -2.95 & $-4.05(0.00)$ & $-1.89(0.33)$ & $-9.82(0.00)$ & $-3.88(0.01)$ & $\mathrm{I}(0)$ \\
GDPr & -2.95 & $-2.86(0.06)$ & $-2.73(0.08)$ & $-5.51(0.00)$ & $-9.40(0.00)$ & $\mathrm{I}(1)$ \\
Inf & -2.95 & $-5.96(0.00)$ & $-5.96(0.00)$ & $-7.37(0.00)$ & $-34.6(0.00)$ & $\mathrm{I}(0)$ \\
Int & -2.95 & $2.05(1.0)$ & $1.93(1.00)$ & $-3.98(0.00)$ & $-4.03(0.00)$ & $\mathrm{I}(1)$ \\
Unemp & -2.95 & $1.69(1.0)$ & $1.48(1.00)$ & $-4.11(0.00)$ & $-4.09(0.00)$ & $\mathrm{I}(1)$ \\
Reer & -2.95 & $-2.00(0.29)$ & $-1.18(0.67)$ & $-4.94(0.00)$ & $-6.06(0.00)$ & $\mathrm{I}(1)$ \\
LnOil $_{G D P}$ & -2.95 & & & & &
\end{tabular}

Source: Authors' computation using E-views 9.0 (2019)

The Auto Regressive Distributed Lags (ARDL) was deployed to estimate the long run relationships in the model because two of the series were stationary at level and the others at first difference. 


\subsection{Estimation Results}

\subsubsection{Co-integration Test Result (Bounds Test)}

The result of the Bounds co-integration pre-test conducted prior to the deployment of the Auto Regressive Distributed Lag Models (ARDL) is presented in Table 3.

Since calculated F-statistic value (5.52) was greater than the 5\% critical value at lower bound (I0) of 2.45 and upper bound value (3.61), a prima facie co-integration existence between the variables has been established.

Table 3. Auto Regressive Distributed Lag Models (ARDL) Bounds test

\begin{tabular}{ccc}
\hline Test Statistic & Value & $\mathrm{k}$ \\
\hline F-statistic & 5.52 & 6 \\
\hline Significance & & Critical Value Bounds \\
\cline { 2 - 3 } & $\mathrm{I}(0)$ Bound & $\mathrm{I}(1)$ Bound \\
\hline $10 \%$ & 2.12 & 3.23 \\
$5 \%$ & 2.45 & 3.61 \\
\hline
\end{tabular}

Source: Authors' computation using E-views 9.0 (2019)

\subsubsection{Long Run Co-integration (ARDL) Test}

The result of the Auto Regressive Distributed Lags long run estimation is presented in Table 4. It is also expressed algebraically in equation 2.

Table 4. Long Run Co-integration (ARDL) Test Result

\begin{tabular}{cccccc}
\hline Variable & Coefficient & Std. Error & t-Statistic & Prob. & Remark \\
\hline GDPr & 0.02 & 0.02 & 4.09 & 0.29 & Significant \\
Inf & 0.004 & 0.01 & 0.82 & 0.42 & Insignificant \\
Int & -0.05 & 0.01 & -3.44 & 0.00 & Significant \\
Unemp & -0.08 & 0.02 & -3.39 & 0.00 & Significant \\
Reer & 0.02 & 0.00 & 4.58 & 0.00 & Significant \\
LnOil $_{G D P}$ & 0.75 & 0.04 & 19.79 & 0.00 & Significant \\
C & 2.75 & 0.27 & 10.15 & 0.00 & Significant \\
\hline
\end{tabular}

Source: Author's computation using E-views 9.0 (2019)

$$
\text { LnAgric }_{G D P}=2.75+0.02 G D P_{r}+0.004 \text { Inf }-0.05 \text { Int }-0.08 \text { Unemp }+0.02 \text { Reer }+0.75 \text { LnOil }{ }_{G D P}
$$

The long run results obtained are mixed. There is a positive and significant relationship between the rate of current year's GDP and the contribution of the agricultural sector to this growth. A percentage rise in the exchange rate will result into a $2 \%$ increase in the agricultural output in the long run. This signifies that a positive and significant relationship exists between exchange rate and agricultural output in the long run.

Inflation rate was insignificant in shaping agriculture but the unemployment rate adversely will bring about $8 \%$ reductions in the agricultural contribution to the GDP. This is explained by the migration from the rural agrarian sector to urban areas. A negative relationship existed between the real interest rate and the agricultural in the long run. A unit increase in the real interest rate precipitated a $5 \%$ reduction in the agricultural sector's contribution to GDP.

The relationship between the oil sector's contributions to GDP and the performance of the agricultural sector was significant. Indeed, $100 \%$ rise in the oil sector's contribution to GDP will bring about a $75 \%$ increase in the agricultural sector contribution to GDP. This is contrary to apriori expectation. The next step is to understand the relationship between the variables in the short run which is contained in the next section.

\subsubsection{Short Run Results}

Table 5. Co-integrating form of the Short Run Results

\begin{tabular}{ccccc}
\hline \multicolumn{5}{c}{ Co-integrating Form Short run results } \\
\hline Variable & Coefficient & Std. Error & t-Statistic & Prob. \\
$\mathrm{D}(G D P r)$ & 0.03 & 0.00 & 6.47 & 0.00 \\
$\mathrm{D}(G D P r(-1))$ & 0.01 & 0.00 & 2.43 & 0.03 \\
$\mathrm{D}($ Inf $)$ & 0.00 & 0.00 & 3.49 & 0.00 \\
\hline
\end{tabular}




\begin{tabular}{ccccc}
\hline $\mathrm{D}($ Int $)$ & -0.01 & 0.00 & -3.61 & 0.00 \\
$\mathrm{D}($ Int $(-1))$ & 0.00 & 0.00 & 2.72 & 0.01 \\
$\mathrm{D}($ Unemp $)$ & -0.02 & 0.01 & -2.13 & 0.04 \\
$\mathrm{D}($ Unemp $(-1))$ & -0.02 & 0.01 & -2.92 & 0.00 \\
$\mathrm{D}($ Reer $)$ & 0.00 & 0.00 & 5.40 & 0.00 \\
$\mathrm{D}($ LnOilgdp $)$ & -0.08 & 0.06 & -1.23 & 0.23 \\
$\mathrm{D}($ LnOilgdp $(-1))$ & -0.25 & 0.08 & -3.26 & 0.00 \\
Cointeq $(-1)$ & -0.31 & 0.07 & -4.48 & 0.00 \\
\hline
\end{tabular}

Source: Author's computation using E-views 9.0 (2019)

The result showed that the coefficient of the error correction term is negative (-0.31) and statistically significant $(0.00)$ at the 0.05 level. This means that with a coefficient of 0.31 per cent which measures the speed of adjustment to equilibrium in the event of displacement, about one-third of the displacement from equilibrium will be corrected in 1 year.

The current year oil sector revenue is not significant in influencing the agricultural sector's output in the short run. However, the previous year's oil output will result in a $25 \%$ reduction in the contribution of agricultural sector to the GDP. A plausible explanation would be that since this study utilised the contributions of both the oil and the agricultural sector to the same base of GDP, a rise in one would led to diminution in the other.

The other variables are significant both in the real time and when lagged by one year. A unit increase in in real time GDP growth rate and lagged GDP will bring about a 1 basis point and 3 unit increase respectively in the output of the agricultural sector. A percentage rise in the exchange rate will bring about no impact on the agricultural output in the short run. In a similar vein, increasing the unemployment rate will bring about a $2 \%$ drop in the agricultural contribution to GDP. This relationship is negative. With respect to real exchange rate, a unit increase in the real interest rate will precipitate a $1 \%$ decline in the agricultural sector's GDP. In the one lag period, the magnitude of reduction is tripled.

\subsection{Post Estimation Test}

\subsubsection{Stability Test: Cumulative Sum Control Chart (CUSUM)}

The result of the CUSUM deployed to test the sequence of residual deviations from a model to and show whether the autoregressive model is mis-specified is shown in Figure 1.

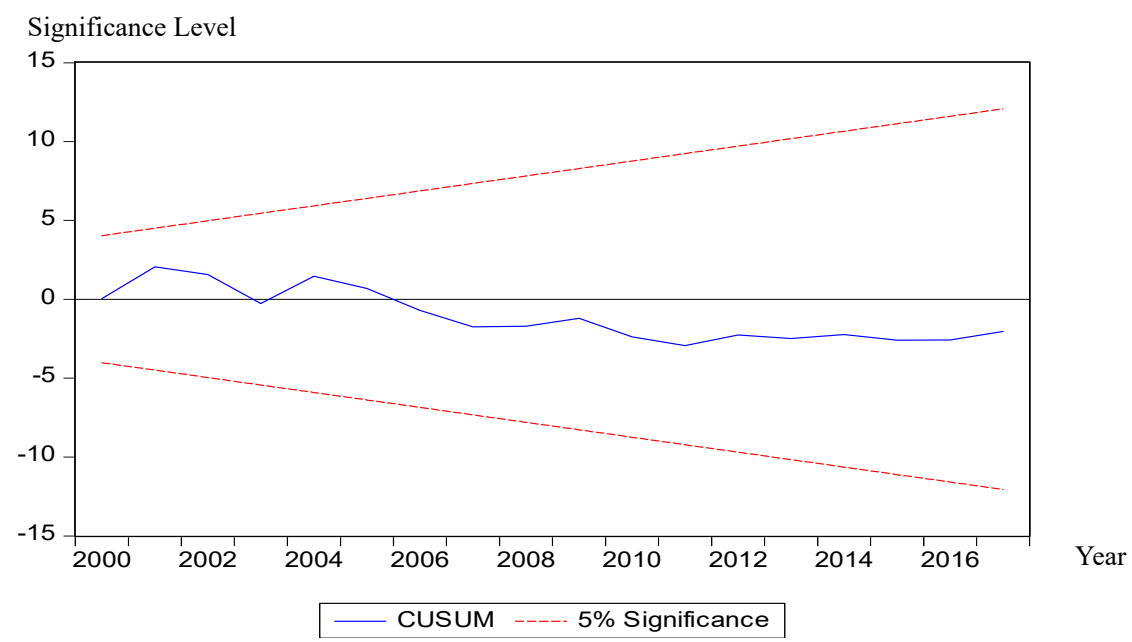

Figure 1. Cumulative Sum Control Chart (CUSUM)

Since the plot of the CUSUM lies within the straight line to present the critical bound at $5 \%$ level which indicates that the model is stable.

\subsubsection{Breusch-Godfrey Serial Correlation Lm Test}

This was deployed to check for the possible serial relationship between the variables. The decision rule being that the null hypothesis should be rejected if the prob.chi square is less than $5 \%$ level of significance. The result is presented in Table 6 . 
Table 6. Results of Breusch-Godfrey Serial Correlation Lm Test

\begin{tabular}{cccc}
\hline F-statistic & 1.45 & Prob. F(2,16) & 0.26 \\
\hline Obs*R-squared & 5.37 & Prob. Chi-Square(2) & 0.06 \\
\hline
\end{tabular}

Source: Authors' computation using E-views 9.0 (2019)

The study accepts the null hypothesis that serial correlation do not exists among the residuals. This is because the calculated prob. (0.06) was greater than the $5 \%$ level of significance.

\subsubsection{Vector Error Correction Residual Normality Test}

The normality test result is presented in Figure 2.

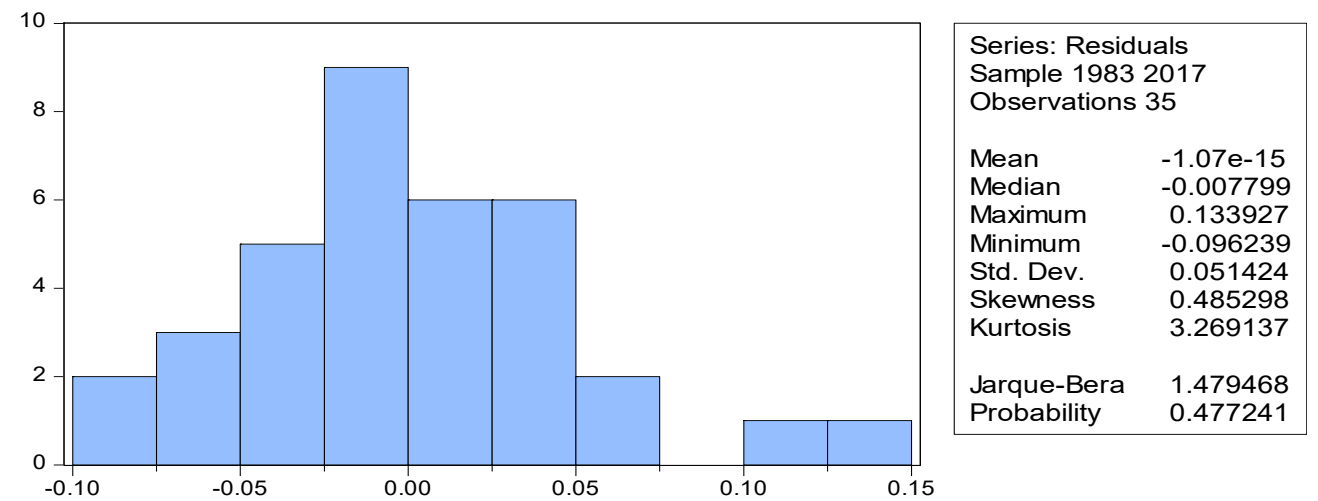

Figure 2. Vector Error Correction Normality Test

The normality distribution of the variables in the model was tested. The null hypothesis was accepted because the estimated critical value of 0.05 was less than the obtained probability value $(0.47)$.

\subsubsection{Vector Error Correction (VEC) Residual Heteroscedasticity Tests}

The heteroscedasticity result presented in Table 7 revealed the constancy of the variability of the error term. This is because the estimated the probability at the $5 \%$ level of significance is less than the Observed R-squared (0.25). The conclusion to be drawn is that there is no heteroscedasticity.

Table 7. Result of Vector Error Correction (VEC) Residual Heteroscedasticity Tests

\begin{tabular}{cccc} 
F-statistic & 1.38 & Prob. F(16,18) & 0.25 \\
Obs*R-squared & 19.31 & Prob. Chi-Square(16) & 0.25 \\
Scaled explained SS & 5.79 & Prob.Chi-Square(16) & 0.99 \\
\hline
\end{tabular}

Source: Authors computation using E-views 9.0 (2019)

\subsection{Discussion of Findings}

Table 8. Summary of Findings

\begin{tabular}{cccccc}
\hline Variable & Coefficient & Std. Error & t-Statistic & Prob. & Remark \\
\hline$G D P_{r}$ & 0.02 & 0.02 & 1.09 & 0.29 & Insignificant \\
Inf & 0.004 & 0.01 & 0.82 & 0.42 & Insignificant \\
Int & -0.05 & 0.01 & -3.44 & 0.00 & Significant \\
Unemp & -0.08 & 0.02 & -3.39 & 0.00 & Significant \\
Reer & 0.02 & 0.00 & 4.58 & 0.00 & Significant \\
LnOil & $0.75 P$ & 0.04 & 19.79 & 0.00 & Significant \\
C & 2.75 & 0.27 & 10.15 & 0.00 & Significant \\
\hline
\end{tabular}

Source: Authors computation using E-views 9.0 (2019)

The result presented in Table 8 showed that exchange rate and the oil sector had positive influence on the agricultural sector's output, while interest and unemployment rate had negative effect. Inflation rate and GDP did not have any relationship or impact.

The result of this research is in congruence with the Solow-Swan growth model theory. The positive relationship between the GDP growth rate and agricultural sector's contribution to GDP is manifest. Although oil revenue is 
still the dominant foreign income earner, the export value of agriculture exports over the decade remained below $2 \%$. However, the agriculture industry is still crucial because it contributed about one-quarter of total GDP in comparison with the contribution of the oil sector which stood at about $8.6 \%$ during the same period. The various government interventions and innovative researches from specialized institutions would have contributed to the changing tide of agricultural output in the country which is consistent with the endogenous growth theory upon which this research is based.

This study also supports the Keynesian preference theory of interest rate which espouses the negative relationship between the interest rate and GDP (in this case agricultural sector's contribution to GDP). Over the years, the interest rate in Nigeria has experienced various fluctuations but the rate has trended up. The continued high interest rate tends to discourage investment in agriculture beyond the subsistence level.

The significant, negative connection between unemployment rate and GDP is also in congruence with the Okun's law. When combined with the endogenous theory, the output growth rate and increase in productivity in the agricultural sector is precipitated by technical amelioration or progress and growth in labour and capital contributions.

With respect to inflation, the study did not support postulations of the Philips curve. Indeed, this research found no significant relationship between inflation and agricultural output. This may be due to the largely agrarian and subsistent nature of agriculture in the economy, with little value-added for commercial impact.

These findings have found congruence and dissention in the literature. The result of the study by Oye, Inuwa and Muhammad (2011), Sunday, Samuel and Inimfon (2015) was in congruence with this study. The negative relationship indicates that a rise in the rate of unemployment will cause the output of agricultural to decline. Agriculture provides about 37 per cent of total employment as of 2017 (World Bank Development Indicators, 2017) therefore, any negative variation if the performance of the sector will significantly portend deleterious consequences for the unemployment rate in the country.

From the results obtained, there was a statistically significant negative relationship between real interest rate and the agricultural sector's contribution to GDP similar to the conclusions reached by Oluwatoyese, Applanaidu and Razak (2016), Vitalis and Millicent (2017). The interest rate represents a key monetary policy tool including inflation targeting to promote economic growth and curb inflation. This finding is in congruence with the a priori expectation since a high interest rate is bound to discourage people from obtaining loans to invest in the agricultural sector.

The results showed that inflation rate is not significantly related to the contribution of the agricultural sector to GDP which is in congruence with the findings of Oluwatoyese, Applanaidu and Razak (2016). The relationship between the GDP growth rate and the agricultural sector's contribution to GDP is positive but insignificant in the long run. This is to be expected as agriculture contributes only about 2 per cent of annual export. The result is in congruence with the findings of Kareem, Bakare, Raheem, Ologunla and Ademoyega (2013).

It was concluded that a long run positive and significant relationship existed between the oil contribution to GDP and the performance of the agricultural sector. This result runs against the gamut of previous finding which has ascribed the diminished performance of agriculture to the discovery and ascendancy of crude oil in Nigeria. One simple explanation would be that the revenue from the oil sector has been channelled to the promotion of other sectors. The more revenue from oil, the greater the capacity of the fiscal and monetary authorities to finance agricultural promotion programmes. The Anchor borrowers' scheme of the Central Bank of Nigeria is a case in point where the apex bank is subsidising the provision of credit facilities to the agricultural and agro-allied industries with the view to increasing the value chain and improve the value adding productivity of the sector.

The result also showed a significant positive connection between the exchange rate and agricultural output which upholds the findings of Adama, Ibrahim and Danjuma (2015). The impact of foreign exchange is reflected in the terms of trade which from the lowest index point of 49.48 in April of 2006, rose to a peak of 160.25 index points in March of 2010. Indeed, the terms of trade in Nigeria averaged 99.13 index points from 2000 until 2019. This improvement has been largely due to crude oil export which accounted for about eighty percent of annual exports. The contribution of the agricultural sector has been steadily on the rise but still miserly $2 \%$ between 2016 and 2018 (PWC, 2019).

\section{Conclusion}

This study investigated the impact of macroeconomic variables and the oil sector on the performance of the agricultural sector between 1981 and 2017. Since the preliminary tests revealed that some of the variables were stationary at level while others demonstrated stationarity at the first difference, the ARDL co-integration method 
was deployed to estimate the model. The results indicated that whereas the output of the agricultural sector was positively influenced by exchange rate and the oil sector. Interest and unemployment rates had negative effect. The rate of inflation rate and the national output had no impact.

Unlocking the potentials of agricultural exports is crucial for national development because in 2018 for example, the sector added about $25 \%$ to total GDP and provided employment for about 37 percent of the population (PWC, 2019), while the much vaunted oil sector provided only $8.6 \%$ of GDP in the same period. Monetary, fiscal and trade policies are required in to boost agricultural output. Policies aimed at promoting value addition to the raw agricultural output are needed, if the country is to harness greater value for its exports. This will involve metamorphosing Nigeria from a supplier of raw materials to a supplier of finished goods. Furthermore, fiscal and monetary and trade policies should be harmonised in order to engender lasting and sustainable growth of the sector.

\section{References}

Adama, I. J., Danjuma. B. F., \& Ibrahim, J. (2015). Macroeconomic Environment and Agricultural Sector Growth: The Nigerian Experience. International Journal of biological and medical research, 6(3), 781-786.

Ali, B. M., Agbo, F. U., Ukwuaba, I. C., \& Chiemela, C. J. (2017). The effects of interest rates on access to agro-credit by farmers in Kaduna State, Nigeria. African Journal of African Research, 12(43), 3160-3168. https://doi.org/10.5897/AJAR2015.9571

Breusch, T. S. (1978). Testing for autocorrelation in dynamic linear models. Australian Economic Papers, 17, 334-355. https://doi.org/10.1111/j.1467-8454.1978.tb00635.x

Dickey, D. A., \& Fuller, W. A. (1979). Distribution of the estimators for autoregressive time series with a unit root. Journal of the American Statistical Association, 74(366), 427-431. https://doi.org/10.1080/01621459.1979.1048253

Dicle, O. (2017). Causal Relationship Between Agricultural Exports And Exchange Rate: Evidence for India. Applied Economics and Finance, 4(6), 36-41.

Enu, P., \& Attah-Obeng-Attah, P. (2013). Impact of Macroeconomic Factors on Foreign Direct Investment in Ghana: A Cointegration Analysis. European Scientific Journal, 9(28), 331-348.

FAO. (2019). Nigeria at a Glance. Retrieved from http://www.fao.org/nigeria/fao-in-nigeria/nigeria-at-aglance/en/

Friedman, M. (1968). The Role of Monetary Policy. American Economic Review, 58(1), 1-17.

Godfrey, L. G. (1978). Testing Against General Autoregressive and Moving Average Error Models When the Regressors Include Lagged Dependent Variables. Econometrica, 46, 1293-1301.

Guo, H., \& Kliesen, K. (2005). Oil Price Volatility and Us Macroeconomic Activity. Review, Federal Reserve Bank of St. Louis, 57(6), 669-683.

Iganiga, B. O., \& Unemhilin, D. O. (2017). The impact of federal government agricultural expenditure on agricultural output in Nigeria. Journal of Economics, 2(2), 81-88 https://doi.org/10.1080/09765239.2011. 11884939

Johansen, S. (1988). Statistical analysis of cointegration vectors. Journal of Economic Dynamics and Control, $12(2-3), 231-254$.

Johansen, S., \& Juselius, K. (1990). Maximum likelihood estimation and inference on cointegration with applications to the demand for money. Oxford Bulletin of Economics and Statistics, 52(2), 169-210.

Jungho, B., \& Won, W. K. (2010). The U.S agricultural sector and the macroeconomy. Journal of Agricultural and Applied Economics, 42(3),457-465.

Kareem, R. O., Bakare, H. A., Raheem, K. A., Ologunla, S. E., Alawode, O. O., \& Ademoyewa, G. R. (2013). Analysis of factors influencing agricultural output in Nigeria: Macro-economics perspectives. American Journal of Business, Economics and Management, 1(1), 9-15.

Keynes, J. M. (1936). The General Theory of Employment, Interest, and Money. London: Macmillan.

Lajos, Z. B., \& Imre, F. (2005). The influence of macroeconomic variables on the Hungarian agriculture. Presentation to the American Agricultural Economics Association 2005 Annual Meeting Providence.

Lucas, R. E. Jr. (1988). On the mechanics of economic development. Journal of Monetary Economics, 22, 73-89. https://doi.org/10.1016/0304-3932(88)90168-7 
Narayan, P., \& Narayan, S. (2007). Modelling oil price volatility. Energy Policy, 35, 6549-6553.

Muftaudeen, O. O., \& Hussainatu, A. (2014). Macroeconomic policy agricultural output in Nigeria: Implications for food security. American Journal of Economics, 4(2), 99-113.

Mousavi, S., \& Leelavathi, D. S. (2013). Agricultural export and exchange rates in India: The Granger causality approach. International Journal of Scientific and Research Publications, 3(2), 1-8.

Myrdal, G. (1968). Asian Drama: An Inquiry into the Poverty of Nations. New York: Pantheon.

National Bureau of statistics. (2017). Social Statistics in Nigeria. Abuja: NBS.

Okun, A. M. (1962). Potential GNP: Its measurement and significance in proceedings of the business and economic statistics section of the American Statistical Association (pp. 89-104). Alexandria, VA: American Statistical Association.

Orji, A., Orji, O. . I. A. \& Okafor, J. C. (2015). Inflation and unemployment nexus in Nigeria: Another test of the phillips curve. Asian Economic and Financial Review, 5(5), 766-778. https://doi.org/10.18488/journal.aefr/ 2015.5.5/102.5.766.778

Oye, N. D., Inuwa, I., \& Muhammad, S. A. (2011). Unemployment in Nigeria : Implication on the gross domestic product $(G D P)$ over the years, 2(1), 66-71.

Oluwatoyese, O. P., Applanaidu, S. D., \& Razak, N. A. A. (2016). Macroeconomic factors and agricultural sector in Nigeria. Procedia - Social and Behavioral Sciences, 219, 562-570. https://doi.org/10.1016/j.sbspro. 2016.05.035

Patrick, E., \& Prudence, A. (2013). Which macro factors influence agricultural production in Ghana. Academic Research International, 4(5), 333-346

Phillips, A. W. (1958). The Relationship between unemployment and the rate of change of money wages in the United Kingdom 1861-1957. Economica, 25(100), 283-299. https://doi.org/10.1111/j.1468-0335.1958. tb00003

Poonyth, D., \& Zyl, J. V. (2000). The impact of real exchange rates changes on South african agricultural exports : An error correction model approach. Agrekon, 39(4), 673-685.

PWC. (2019). Unlocking Nigeria's agricultural exports. Retrieved from https://www.pwc.com $>$ assets $>$ pdf $>$ unloc.

Sunday, B. A., Samuel, J. U., \& Inimfon, V. P. (2015). Roles of macroeconomicvariables on agricultural diversification in Nigeria. American Journal of Economics and Business Administration, 7(2), 77-93.

Romer, P. M. (1990). Endogenous Technological Change. Journal of Political Economy, 98. https://doi.org/10.1086/261725

Salisu, A. A., \& Fasayan, I. O. (2013). Modelling oil price volatility with structural breaks. Energy Policy, 52, 554-562.

Samuelson, P. A., \& Solow, R. M. (1960). Analytical aspects of anti-inflation policy. American Economic Review, 50(2), 177-194.

Solow, R. M. (1956). A Contribution to the theory of economic growth. Quarterly Journal of Economics (Oxford Journals), 70(1), 65-94.

Sylvester, O. (2018). The Nigerian economy before the discovery of crude oil, the political ecology of oil and gas activities in the Nigerian aquatic ecosystem. https://doi.org/10.1016/B978-0-12-809399-3.00005-7 71-81

Tradingeconomics. (2018). Nigeria GDP from Agriculture. Retrieved from https://www.tradingeconomics.com

Vitalis, O. O., \& Millicent, A. O. (2017). The impact of macroeconomic variables on agricultural infrastructure investment and output in Kenya (2005 to 2016). J. of Econ. \& Sustainable Development, 8(22), 182-191.

World Development Indicators. (2017). Retrieved from https://www.openknowledge.worldbank.org/handle/ $10986 / 26447$

\section{Copyrights}

Copyright for this article is retained by the author(s), with first publication rights granted to the journal.

This is an open-access article distributed under the terms and conditions of the Creative Commons Attribution license (http://creativecommons.org/licenses/by/4.0/). 